Article

\title{
Inhibitory Effects of Constituents from the Aerial Parts of Rosmarinus officinalis L. on Triglyceride Accumulation
}

\author{
Jian Li ${ }^{1}$, Tiwalade Adegoke Adelakun ${ }^{1}$, Sijian Wang ${ }^{2}$, Jingya Ruan ${ }^{1}$, Shengcai Yang ${ }^{1}$, \\ Xiaoxia Li ${ }^{1}$, Yi Zhang ${ }^{1,2, *}$ and Tao Wang ${ }^{1,2, *}$ \\ 1 Tianjin State Key Laboratory of Modern Chinese Medicine, 312 Anshanxi Road, Nankai District, \\ Tianjin 300193, China; beyondwill@126.com (J.L.); tiwa_ade@yahoo.com (T.A.A.); \\ Ruanjy19930919@163.com (J.R.); 15122473723@163.com (S.Y.); huifeidedouzi@yeah.net (X.L.) \\ 2 Tianjin Key Laboratory of TCM Chemistry and Analysis, Institute of Traditional Chinese Medicine, \\ Tianjin University of Traditional Chinese Medicine, 312 Anshanxi Road, Nankai District, Tianjin 300193, \\ China; 15122587883@163.com \\ * Correspondence: zhwwxzh@263.net (Y.Z.); wangtao@tjutcm.edu.cn (T.W.); Tel./Fax: +86-22-5959-6163 (T.W.) \\ Academic Editors: Celestino Santos-Buelga and Arturo San Feliciano \\ Received: 10 November 2016; Accepted: 8 January 2017; Published: 17 January 2017
}

\begin{abstract}
Sixteen flavonoids (1-16) including two new ones, named officinoflavonosides A (1) and B (2) were obtained from the aerial parts of Rosmarinus officinalis. Among the known ones, 6, 10, and 13 were isolated from the rosmarinus genus for the first time. Their structures were elucidated by chemical and spectroscopic methods. Moreover, the effects on sodium oleate-induced triglyceride accumulation (TG) in HepG2 cells of the above-mentioned compounds and 16 other isolates (17-32) reported previously to have been obtained in the plant were analyzed. Results show that eight kinds of flavonoids (compounds 1, 2, 3, 6-9 and 11) and seven kinds of other known isolates (compounds 17-20, 23, 26 and 31) possessed significant inhibitory effects on intracellular TG content in HepG2 cells. Among them, the activities of compounds $\mathbf{1}$ and $\mathbf{2 0}$ were comparable to that of orlistat, which suggested that these compounds in this plant might be involved in lipid metabolism.
\end{abstract}

Keywords: Rosmarinus officinalis; flavonoids; terpenoids; phenolic acids; triglyceride accumulation inhibitory effects; HepG2 cells

\section{Introduction}

Rosmarinus officinalis L., is a perennial edible herb, belonging to Labiatae, commonly known as rosemary. $R$. officinalis extract has been reported to have antioxidant, anti-inflammatory, antidiabetic and anticancer properties [1]. In the course of our characterization studies on bioactive constituents from the aerial parts of $R$. officinalis, the isolation and structure elucidation of 16 terpenoids including normonoterpenoid, diterpenoid and triterpenoid glycosides [2], had been reported by us. Their structures were elucidated by chemical and spectroscopic methods. As a continuing study on the plant, we obtained 16 flavonoids including two new ones, named officinoflavonosides A (1) and B (2). In this paper, we describe the isolation and structure elucidation of these new flavanoids, along with the triglyceride (TG) accumulation inhibitory effects of the above-mentioned 45 compounds in HepG2 cells.

\section{Results and Discussion}

During the course of our continuous studies on bioactive constituents from $95 \% \mathrm{EtOH}$ eluate of D101 CC and $\mathrm{CHCl}_{3}$ layer [2,3] from $R$. officinalis aerial parts, 16 flavonoids, including two new compounds, named officinoflavonosides A (1) and B (2) (Figure 1), together with 14 known ones, luteolin-7-O- $\beta$-D-glucoside (3) [3], luteolin-7-O- $\beta$-D-lutinoside (4) [4], luteolin $3^{\prime}$-O- $\beta$-D-glucuronide 


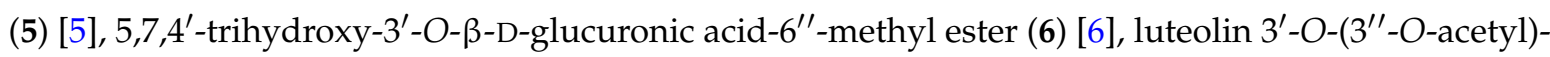
$\beta$-D-glucuronide (7) [5], luteolin $3^{\prime}-O-\left(4^{\prime \prime}-O\right.$-acetyl)- $\beta$-D-glucuronide (8) [5], acacetin (9) [7], tiliadin (10) [8], apigenin-7-O- $\beta$-D-lutinoside (11) [4], nepitrin (12) [9], $6^{\prime \prime}-O-(E)-p$-coumaroylnepitrin (13), 6"-O-(E)-feruloylnepitrin (14), 6-hydroxy luteolin-7-O- $\beta$-D-glucopyranoside (15) [10], and homoplantaginin (16) [11] (Figure 2) were further obtained. Among the known ones, 6, 10, and 13 were isolated from the rosmarinus genus 14 for the first time, and the NMR data of $\mathbf{1 3}$ and $\mathbf{1 4}$ in DMSO- $d_{6}$ were reported for the first time.
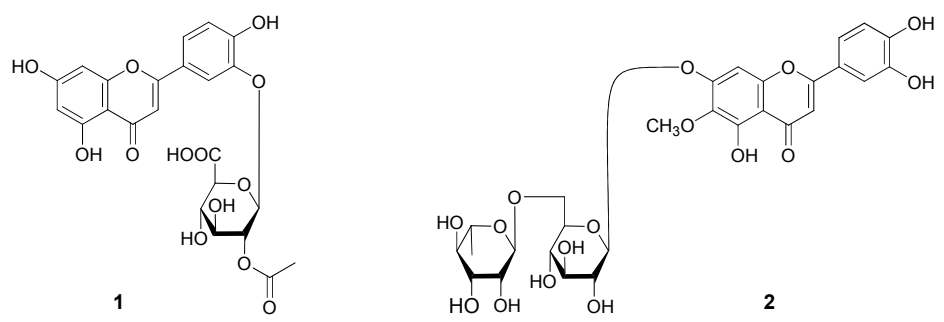

Figure 1. The new compounds 1 and 2 obtained from the aerial parts of R. officinalis.
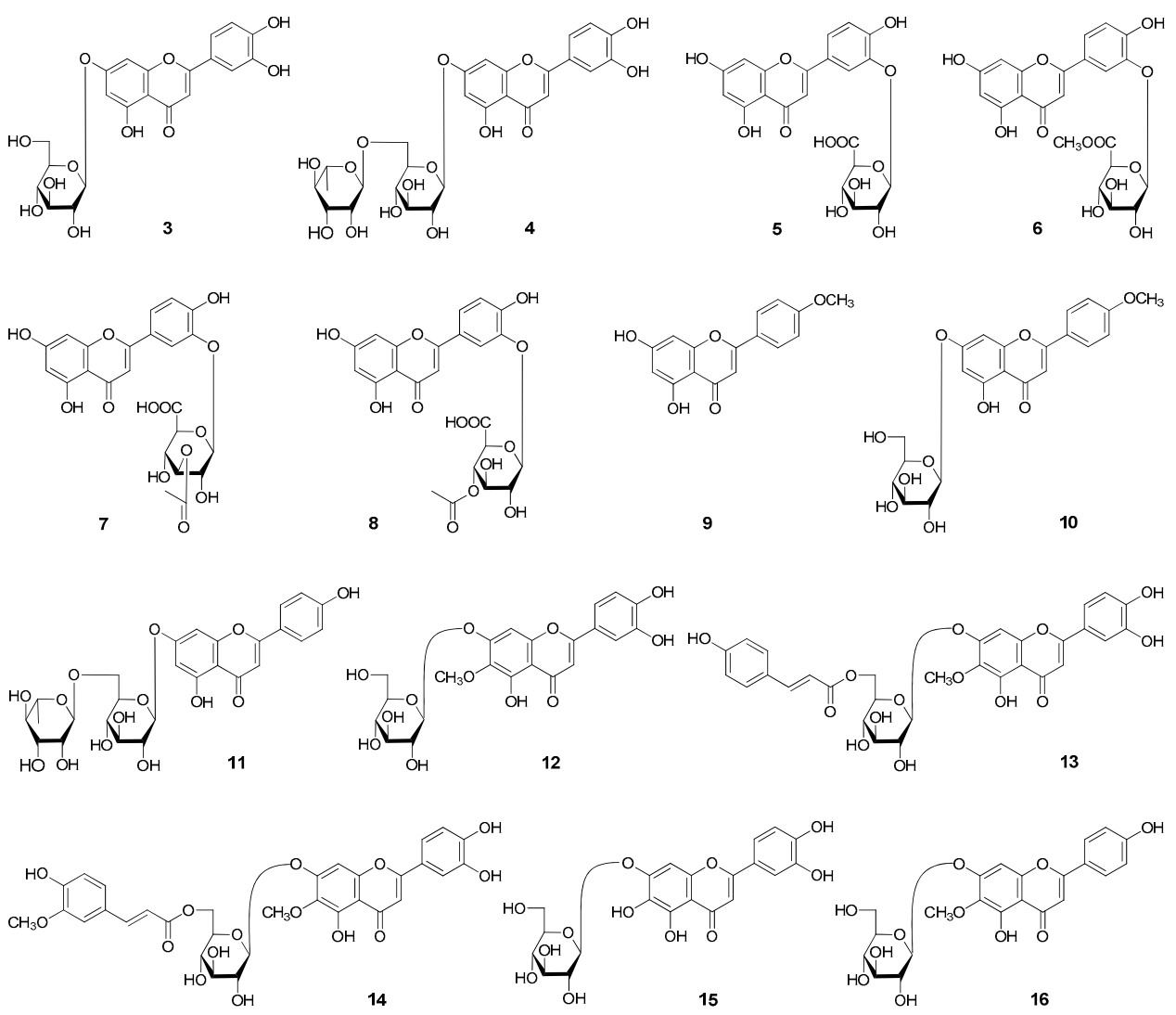

Figure 2. The known flavonoids (3-16) obtained from the aerial parts of R. officinalis.

This paper will elucidate the isolation and structure of new compounds, officinoflavonosides A (1) and B (2). Meanwhile, the effects of 16 flavonoids and 16 previously isolated terpenoids [2], officinoterpenoside D (17), (1S,4S,5S)-5-exo-hydrocamphor 5-O- $\beta$-D-glucopyranoside (18), isorosmanol (19), rosmanol (20), 7-methoxyrosmanol (21), epirosmanol (22), officinoterpenosides $A_{1}$ (23) and $A_{2}$ (24), along with ursolic acid (25), micromeric acid (26), glucosyl tormentate (27), officinoterpenoside $B$ (28), niga-ichigoside $F_{1}$ (29), oleanolic acid (30), officinoterpenoside $C$ (31), asteryunnanoside $B$ (32) (Figure 3) on the reduction of TG content in HepG2 cells were determined. 

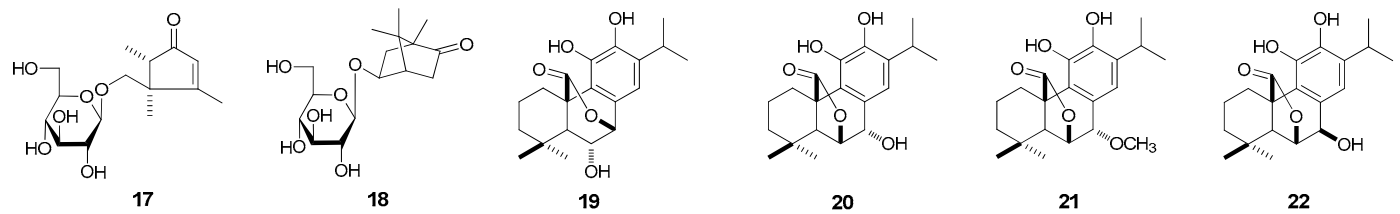

20
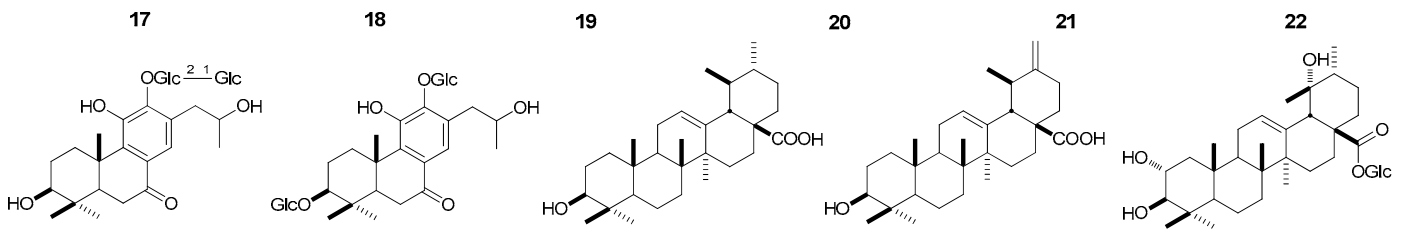

23

24

25

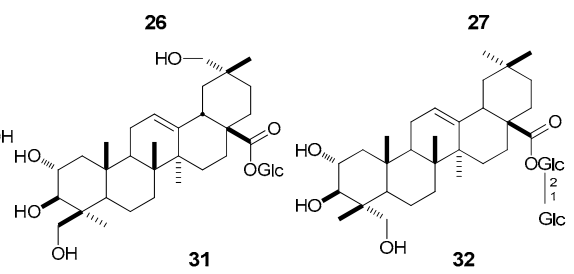

Figure 3. The known terpenoids (17-32) [2,3] obtained from the aerial parts of $R$. officinalis (Glc: $\beta$-D-glucopyranosyl).

Officinoflavonoside $A(\mathbf{1})$ was isolated as an amorphous yellow powder with negative rotation $\left\{[\alpha]_{D}^{25}-11.9^{\circ}(c=0.79, \mathrm{MeOH})\right\}$. Its molecular formula was determined to be $\mathrm{C}_{23} \mathrm{H}_{20} \mathrm{O}_{13}$ by negative-ion HRESI-TOF-MS $\left(m / z 503.0838[\mathrm{M}-\mathrm{H}]^{-}\right.$, calcd for $\mathrm{C}_{23} \mathrm{H}_{19} \mathrm{O}_{13}$ 503.0831). Acid hydrolysis of 1 yielded D-glucuronic acid, which was identified by comparing the $R_{\mathrm{f}}$ value on TLC plate with the authentic sample. The ${ }^{1} \mathrm{H}$ - and ${ }^{13} \mathrm{C}-\mathrm{NMR}$ (Table 1 ) spectra of $\mathbf{1}$, which were assigned by various NMR experiments including ${ }^{1} \mathrm{H}^{-1} \mathrm{H}$ COSY, HSQC, and $\mathrm{HMBC}$ spectra, indicated there was a luteolin part $(\delta 6.21(1 \mathrm{H}$, br. s, H-6), $6.51(1 \mathrm{H}$, br. s, H-8), $6.81(1 \mathrm{H}, \mathrm{s}, \mathrm{H}-3), 7.01(1 \mathrm{H}, \mathrm{d}, J=8.0 \mathrm{~Hz}, \mathrm{H}-5)$ ') $7.66(1 \mathrm{H}$, br. d, ca. $\left.J=8 \mathrm{~Hz}, \mathrm{H}-6^{\prime}\right), 7.69(1 \mathrm{H}$, br. s, H-2'), $12.94(1 \mathrm{H}$, br. s, 5-OH)), a $\beta$-D-glucuronyl moiety $\left(\delta 5.39\left(1 \mathrm{H}, \mathrm{d}, J=8.0 \mathrm{~Hz}, \mathrm{H}-1^{\prime \prime}\right)\right)$, together with an acetyl group $\left(\delta_{\mathrm{H}} 2.07(3 \mathrm{H}, \mathrm{s}) ; \delta_{\mathrm{C}} 20.9\left(\mathrm{COCH}_{3}\right)\right.$, $\left.169.1\left(\mathrm{COCH}_{3}\right)\right)$ in the structure. A downfield shift of $0.3 \mathrm{ppm}$ for the $\mathrm{C}-2^{\prime \prime}$, and upfield shift by $2.0 \mathrm{ppm}$ both for the C- $1^{\prime \prime}$ and $3^{\prime \prime}$ compared with those of luteolin $3^{\prime}-O-\beta$-D-glucuronide (5) [5], which indicated that the $\mathrm{C}-2^{\prime \prime}$ hydroxyl proton was substituted with an acetyl group. Finally, the linkages of $\beta$-D-glucuronyl moiety and acetyl group were clarified on the basis of HMBC experiment, which showed long-range correlations from $\delta_{\mathrm{H}} 5.39\left(\mathrm{H}-1^{\prime \prime}\right)$ to $\delta_{\mathrm{C}} 144.9\left(\mathrm{C}-3^{\prime}\right) ; \delta_{\mathrm{H}} 4.89(1 \mathrm{H}, \mathrm{dd}, J=8.0,8.0 \mathrm{~Hz}$, $\left.\mathrm{H}-2^{\prime \prime}\right)$ to $\delta_{\mathrm{C}} 169.1\left(2-\mathrm{OCOCH}_{3}\right)$ (Figure 4). On the basis of the above-mentioned evidence, the structure of officinoflavonoside A was determined as luteolin $3^{\prime}-O-\left(2^{\prime \prime}-O\right.$-acetyl)- $\beta$-D-glucuronide (1).

Table 1. ${ }^{1} \mathrm{H}$ - and ${ }^{13} \mathrm{C}-\mathrm{NMR}$ data for $\mathbf{1}$ in DMSO- $d_{6}$.

\begin{tabular}{cccccc}
\hline No. & $\delta_{\mathbf{C}}$ & $\delta_{\mathbf{H}}(\boldsymbol{J}$ in Hz) & No. & $\delta_{\mathbf{C}}$ & $\delta_{\mathbf{H}}(\boldsymbol{J}$ in Hz) \\
\hline 2 & 163.2 & - & $4^{\prime}$ & 151.7 & - \\
3 & 103.1 & $6.81(\mathrm{~s})$ & $5^{\prime}$ & 116.8 & $7.01(\mathrm{~d}, 8.0)$ \\
4 & 181.7 & - & $6^{\prime}$ & 122.4 & $7.66(\mathrm{br} . \mathrm{d}, \mathrm{ca} .8)$ \\
5 & 161.4 & - & $1^{\prime \prime}$ & 98.8 & $5.39(\mathrm{~d}, 8.0)$ \\
6 & 98.8 & 6.21 (br. s) & $2^{\prime \prime}$ & 73.2 & $4.89(\mathrm{dd}, 8.0,8.0)$ \\
7 & 164.2 & - & $3^{\prime \prime}$ & 73.4 & $3.57(\mathrm{dd}, 8.0,8.0)$ \\
8 & 94.0 & 6.51 (br. s) & $4^{\prime \prime}$ & 71.5 & $3.55(\mathrm{dd}, 8.0,8.0)$ \\
9 & 157.2 & - & $5^{\prime \prime}$ & 75.2 & $4.01(\mathrm{~d}, 8.0 \mathrm{~Hz})$ \\
10 & 103.6 & - & $6^{\prime \prime}$ & 170.3 & - \\
$1^{\prime}$ & 121.3 & - & $2^{\prime \prime}-\mathrm{COCH}_{3}$ & 169.1 & - \\
$2^{\prime}$ & 115.7 & 7.69 (br. s) & $2^{\prime \prime}-\mathrm{COCH}_{3}$ & 20.9 & $2.07(\mathrm{~s})$ \\
$3^{\prime}$ & 144.9 & - & $5-\mathrm{OH}$ & - & $12.94(\mathrm{br} . \mathrm{s})$ \\
\hline
\end{tabular}



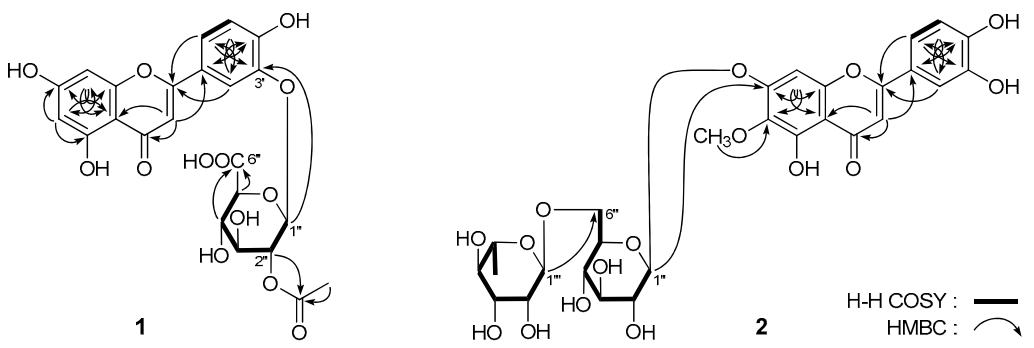

Figure 4. The main ${ }^{1} \mathrm{H}^{1}{ }^{\mathrm{H}} \mathrm{COSY}$ and $\mathrm{HMBC}$ correlations of $\mathbf{1}$ and 2.

Officinoflavonoside B (2) with negative optical rotation $\left([\alpha]_{\mathrm{D}}^{25}-47.4^{\circ}\right.$ in $\left.\mathrm{MeOH}\right)$ was also isolated as an amorphous yellow powder. The molecular formula $\mathrm{C}_{28} \mathrm{H}_{30} \mathrm{O}_{16}$ of 2 was determined from negative-ion HRESI-TOF-MS $\left(\mathrm{m} / \mathrm{z} 623.1595[\mathrm{M}-\mathrm{H}]^{-}\right.$, calcd for $\left.\mathrm{C}_{28} \mathrm{H}_{31} \mathrm{O}_{16} 623.1618\right)$, too. The IR spectrum exhibited typical absorption bands of hydroxyl $\left(3332 \mathrm{~cm}^{-1}\right)$, ester carboxyl group $\left(1658 \mathrm{~cm}^{-1}\right)$, aromatic ring $\left(1603,1514,1462 \mathrm{~cm}^{-1}\right)$, and an $O$-glycosidic linkage $\left(1067 \mathrm{~cm}^{-1}\right)$. The UV data of 2 showed the characteristic maxima absorption of luteolin aglycon at $340 \mathrm{~nm}(4.17)$ and $267 \mathrm{~nm}(4.11)$. Acid hydrolysis of 2 with $1.0 \mathrm{M} \mathrm{HCl}$ liberated L-rhamnose and D-glucose, which were identified by HPLC analysis using an optical rotation detector [2]. The ${ }^{1} \mathrm{H}-$ and ${ }^{13} \mathrm{C}-\mathrm{NMR}$ (Table 2) spectra of 2 indicated the presence of 6-methoxy luteolin (nepitrin) $(\delta 6.70(1 \mathrm{H}, \mathrm{s}, \mathrm{H}-3), 6.89(1 \mathrm{H}, \mathrm{s}, \mathrm{H}-8), 6.90$ $\left.\left(1 \mathrm{H}, \mathrm{d}, J=8.0 \mathrm{~Hz}, \mathrm{H}-5^{\prime}\right), 7.40\left(1 \mathrm{H}, \mathrm{dd}, J=2.0,8.0 \mathrm{~Hz}, \mathrm{H}-6^{\prime}\right), 7.41\left(1 \mathrm{H}, \mathrm{d}, J=2.0 \mathrm{~Hz}, \mathrm{H}-2^{\prime}\right)\right)$, and a $\beta$-D-glucopyranosyl $\left(\delta 5.13\left(1 \mathrm{H}, \mathrm{d}, J=7.5 \mathrm{~Hz}, \mathrm{H}-1^{\prime \prime}\right)\right)$, together with an $\alpha$-L-rhamnopyranosyl moiety $\left(\delta 1.05\left(3 \mathrm{H}, \mathrm{d}, J=6.5 \mathrm{~Hz}, \mathrm{H}-6^{\prime \prime \prime}\right), 4.57\left(1 \mathrm{H}, \mathrm{br} . \mathrm{s}, \mathrm{H}-\mathrm{-}^{\prime \prime \prime}\right)\right)$. The connectivity of oligoglycoside moieties to the aglycon part was characterized by a HMBC experiment on 2. Thus, the HMBC experiment of 2 showed long-range correlations between the following proton and carbon pairs $\left(\delta_{\mathrm{H}} 5.13\left(1^{\prime \prime}-\mathrm{H}\right)\right.$ and $\delta_{\mathrm{C}} 156.3$ $(\mathrm{C}-7) ; \delta_{\mathrm{H}} 4.57\left(\mathrm{H}-1^{\prime \prime \prime}\right)$ and $\left.\delta_{\mathrm{C}} 65.8\left(\mathrm{C}-6^{\prime \prime}\right)\right)$ (Figure 4). Consequently, the structure of officinoflavonoside $\mathrm{B}$ was determined to be nepitrin $7-O-\alpha-\mathrm{L}$-rhamnopyranosyl $(1 \rightarrow 6)-\beta$-D-glucopyranoside (2).

Table 2. ${ }^{1} \mathrm{H}$ - and ${ }^{13} \mathrm{C}-\mathrm{NMR}$ data for 2 in DMSO- $d_{6}$.

\begin{tabular}{|c|c|c|c|c|c|}
\hline No. & $\delta_{C}$ & $\delta_{H}(J$ in $\mathrm{Hz})$ & No. & $\delta_{C}$ & $\delta_{H}(J$ in $\mathrm{Hz})$ \\
\hline 2 & 164.8 & - & $1^{\prime \prime}$ & 100.3 & $5.13(\mathrm{~d}, 7.5)$ \\
\hline 3 & 102.4 & $6.70(\mathrm{~s})$ & $2^{\prime \prime}$ & 73.1 & $3.32(\mathrm{~m}$, overlapped $)$ \\
\hline 4 & 182.0 & - & $3^{\prime \prime}$ & 76.4 & 3.32 (m, overlapped) \\
\hline 5 & 152.7 & - & $4^{\prime \prime}$ & 69.4 & $3.21(\mathrm{dd}, 9.0,9.0)$ \\
\hline 6 & 132.7 & - & $5^{\prime \prime}$ & 75.5 & $3.61(\mathrm{~m})$ \\
\hline 7 & 156.3 & - & $6^{\prime \prime}$ & 65.8 & $3.51(\mathrm{dd}, 4.5,12.0)$ \\
\hline 8 & 94.2 & $6.89(\mathrm{~s})$ & & & 3.85 (br. d, ca. 12) \\
\hline 9 & 152.1 & - & $1^{\prime \prime \prime}$ & 100.3 & 4.57 (br. s) \\
\hline 10 & 105.8 & - & $2^{\prime \prime \prime}$ & 70.3 & 3.64 (br. d, ca. 3) \\
\hline $1^{\prime}$ & 120.7 & - & $3^{\prime \prime \prime}$ & 70.7 & $3.46(\mathrm{dd}, 3.0,9.0)$ \\
\hline $2^{\prime}$ & 113.2 & $7.41(\mathrm{~d}, 2.0)$ & $4^{\prime \prime \prime}$ & 71.9 & $3.15(\mathrm{dd}, 9.0,9.0)$ \\
\hline $3^{\prime}$ & 146.2 & - & $5^{\prime \prime \prime}$ & 68.2 & $3.42(\mathrm{~m})$ \\
\hline $4^{\prime}$ & 150.8 & - & $6^{\prime \prime \prime}$ & 17.7 & $1.05(\mathrm{~d}, 6.5)$ \\
\hline $5^{\prime}$ & 115.9 & $6.90(\mathrm{~d}, 8.0)$ & $6-\mathrm{OCH}_{3}$ & 60.2 & $3.77(\mathrm{~s})$ \\
\hline $6^{\prime}$ & 119.0 & $7.40(\mathrm{dd}, 2.0,8.0)$ & $5-\mathrm{OH}$ & - & 13.06 (br. s) \\
\hline
\end{tabular}

TG accumulation of inhibitory effects of compounds isolated from aerial parts of $R$. officinalis were screened in sophisticated sodium oleate (SO)-induced HepG2 cells. The results showed that TG was accumulated as lipid droplets in the SO treated HepG2 cells monolayer and at least a 5 -fold increase $(p<0.001)$ in TG content was observed from $51.14 \pm 4.70 \mathrm{mg} / \mathrm{dL}$ (normal group) to $288.34 \pm 5.72 \mathrm{mg} / \mathrm{dL}$ (model group). Compared to the SO group, orlistat significantly $(p<0.001$ ) decreased this value to $230.06 \pm 2.68 \mathrm{mg} / \mathrm{dL}$ by a $20.2 \%$ clearance ratio and eight of the 16 kinds of flavonoids tested showed similar inhibitory effects. Compounds 1, 2, 3, 6-9 and 11 reduced the 
intracellular TG content by 17.0\%, 8.4\%, 9.8\%, 9.7\%, 11.3\%, 8.5\%, 13.0\% and $6.0 \%$, respectively, as given in Figure 5A. In addition, 16 terpenoids (17-32) were evaluated in the same method and seven kinds showed significantly inhibitory activities. The clearance ratios of 17-20, 23, 26 and 31 were 6.3\%, 8.3\%, $8.4 \%, 23.3 \%, 5.8 \%, 8.4 \%$ and $8.5 \%$, respectively, as given in Figure 5B.

$\mathbf{A}$

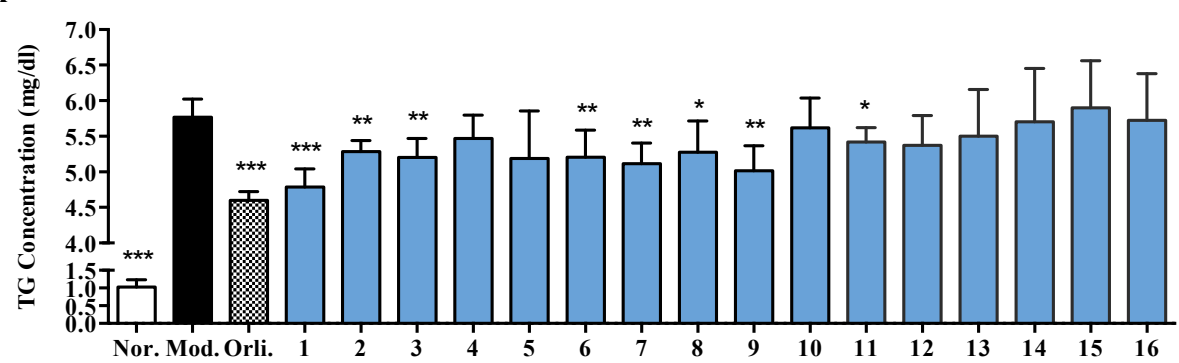

B

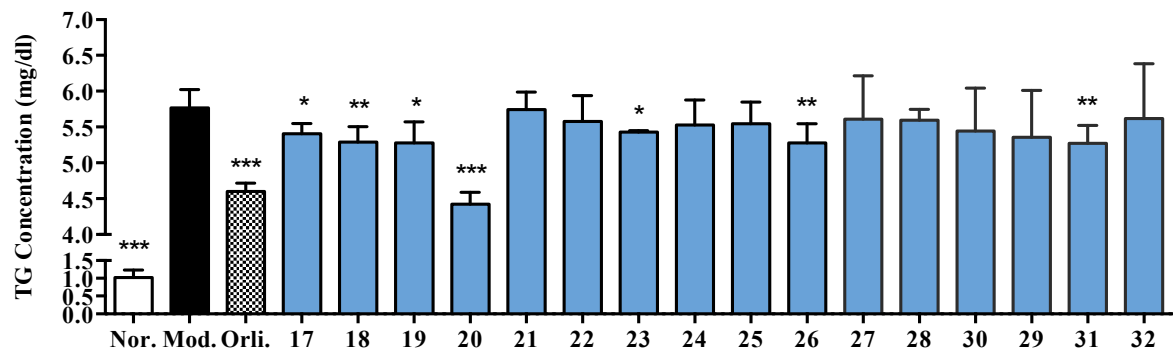

Figure 5. (A) Effects of 16 kinds of flavonoids (1-16) from R. officinalis on triglyceride (TG) accumulation in HepG2 cells; (B) Effects of 16 terpenoids (17-32) from R. officinalis on TG accumulation in HepG2 cells. Cells were incubated with $200 \mu \mathrm{mol} / \mathrm{L}$ SO for $48 \mathrm{~h}$. Meanwhile, tested compounds ( $30 \mu \mathrm{mol} / \mathrm{L})$ and positive-controlled orlistat $(5 \mu \mathrm{mol} / \mathrm{L}$, Orli.) were co-incubated to evaluate their inhibitory effects. Cells cultured in normal medium without sodium oleate (SO) were set as normal group (Nor.). The intracellular TG content in each well was examined using a TG assay kit. Each value represents the mean \pm S.E.M., $n=5,{ }^{* * *} p<0.001,{ }^{* *} p<0.01,{ }^{*} p<0.05$ vs. model group (Mod.).

Studies of dose dependency of six selected compounds (compounds 1, 2, 9, 20, 26 and 31), which comparatively showed the best TG-lowering activities, were then conducted. In this system, orlistat, a lipase inhibitor showed significant TG accumulation effects at concentration of $5 \mu \mathrm{mol} / \mathrm{L}$. As shown in Figure 6, the results revealed that all the above isolates could inhibit the SO-induced intracellular TG accumulation in a dose dependent manner. Among them, compound 20 exhibited the strongest activity that it had demonstrated a clearance ratio of more than $5.6 \%$ from $1 \mu \mathrm{mol} / \mathrm{L}$. Then, Oil red O staining further visually confirmed the results that a large amount of lipid droplets were seen in SO-treated HepG2 cells, indicating lipid accumulation, but the accumulation was inhibited by compound 20 in a dose dependent manner (shown in Figure 7). Although the colorimetric assay results showed that the concentration of $1 \mu \mathrm{mol} / \mathrm{L}$ exhibited no significant difference compared to the model group, the possible reasons for this might be the lower precision of this detection method or the activity-instability at this low concentration.

Although a limited number of compounds were tested for inhibitory effects on TG accumulation in HepG2 cells, we can summarize the structure-activities relationship as follows: in flavonoids, 5,7-dihydroxyl substitution showed strong activities (compounds 1, 6-9), and the activities would be reduced when 7-hydroxyl group was glucosylated (Compound $9>10$ ). Among the diterpenes, compound 20 showed strongest inhibitory effect on TG accumulation. Methylation or configuration changing at position 20 would quench the activity, which indicated that $20 \alpha$-hydroxy is important for inhibitory activity. 
A
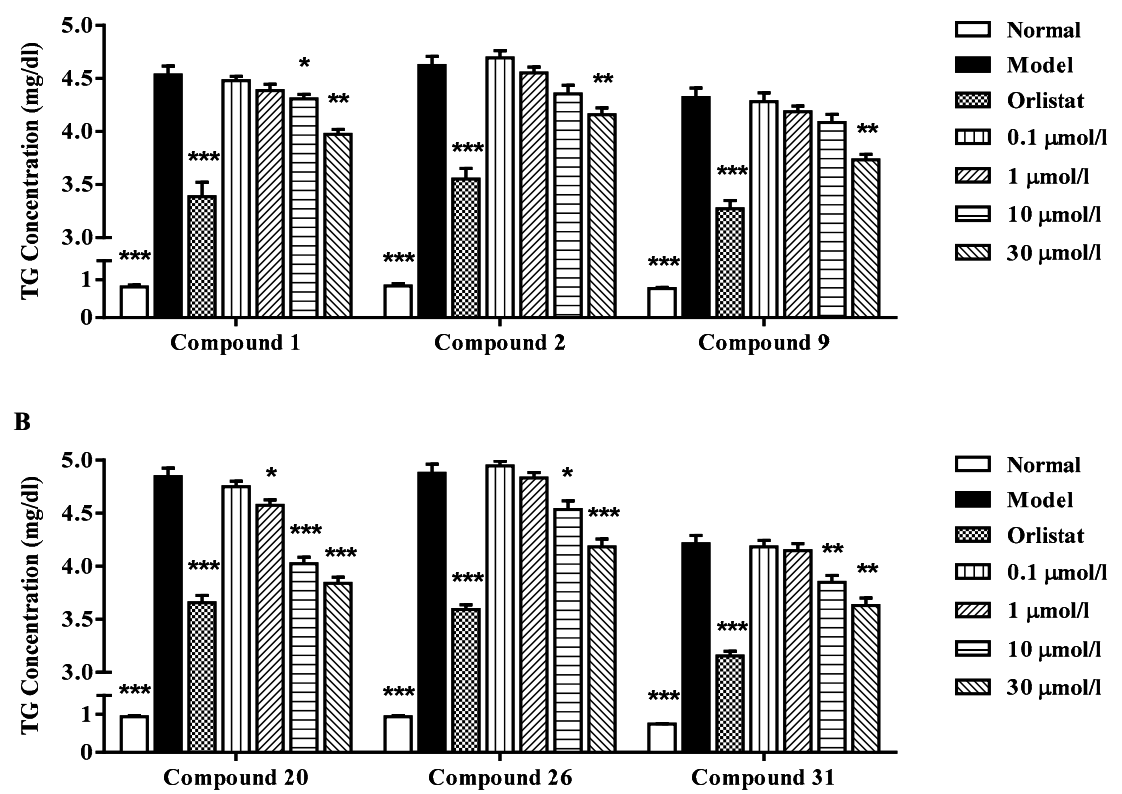

Figure 6. Dose dependency of TG-lowering effects of compounds 1, 2, 9, 20, 26 and 31 in HepG2 cells. HepG2 cells were treated with $0,0.1,1,10$ and $30 \mu \mathrm{mol} / \mathrm{L}$ of indicated compounds, respectively in the presence of SO for $48 \mathrm{~h}$. Rate of TG lowering is given according to a formula: Rate of TG lowering $(\%)=((\mathrm{TG}$ concentration of untreated groups $-\mathrm{TG}$ concentration of treated groups $) / \mathrm{TG}$ concentration of untreated groups) $\times 100 \%$. Each value represents the mean \pm S.E.M., $n=5,{ }^{* * *} p<0.001{ }^{* *} p<0.01{ }^{*} p<0.05$ vs. untreated controls. (A) effects of Compounds 1, 2 and 9; (B) effects of Compounds 20, 26 and 31.
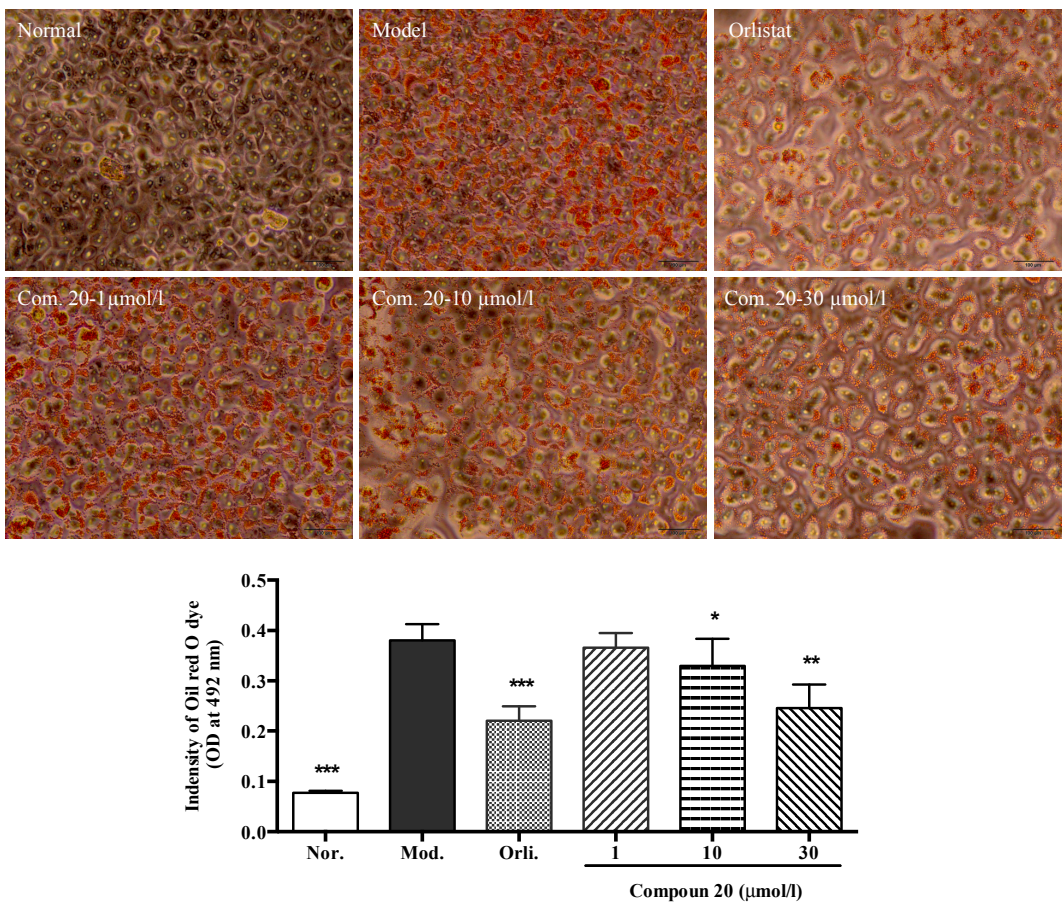

Figure 7. Effect of compound 20 from R. officinalis on TG accumulation in HepG2 cells. HepG2 cells were treated with indicated concentrations of orlistat (orlistat group, Orli.) or compound 20 in the absence (normal group, Nor.) or presence of SO for $48 \mathrm{~h}$. Cells were stained with Oil Red O (A) and analyzed by colorimetric assay at $492 \mathrm{~nm}($ B). Each value represents the mean \pm S.E.M., $n=4$, ${ }^{* * *} p<0.001,{ }^{* *} p<0.01,{ }^{*} p<0.05$ vs. model group (Mod.). 


\section{Experimental Section}

\subsection{General}

Optical rotations were determined on a Rudolph Autopol ${ }^{\circledR}$ IV automatic polarimeter $(1=50 \mathrm{~mm})$. IR spectra were recorded on a Varian 640-IR FT-IR spectrophotometer (Varian Australia Pty Ltd., Mulgrave, Australia). UV spectra were obtained on a Varian Cary 50 UV-Vis spectrophotometer (Varian, Inc., Hubbardsdon, MA, USA). NMR spectra were measured at a Bruker $500 \mathrm{MHz}$ NMR spectrometer (Bruker BioSpin AG Industriestrasse $26 \mathrm{CH}-8117$, Fällanden, Switzerland) at $500 \mathrm{MHz}$ for ${ }^{1} \mathrm{H}$ - and $125 \mathrm{MHz}$ for ${ }^{13} \mathrm{C}-\mathrm{NMR}$, with TMS as an internal standard. Positive- and Negative-ion HRESI-TOF-MS were recorded on an Agilent Technologies 6520 Accurate-Mass Q-Tof LC/MS spectrometer (Agilent Corp., Santa Clara, CA, USA).

Column chromatographies (CC) were conducted on macroporous resin D101 (Haiguang Chemical Co., Ltd., Tianjin, China), Silica gel (74-149 $\mu \mathrm{m}$, Qingdao Haiyang Chemical Co., Ltd.,

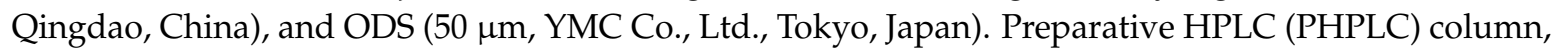
Cosmosil 5C 18 -MS-II (20 mm i.d. $\times 250 \mathrm{~mm}$, Nakalai Tesque, Inc., Tokyo, Japan) was used to purify the constituents.

\subsection{Plant Material}

The dried aerial parts of $R$. officinalis were collected from Butarie, Rwanda, and identified by Dr. Li Tianxiang (Experiment Teaching Department, Tianjin University of Traditional Chinese Medicine). The voucher specimen was deposited at the Academy of Traditional Chinese Medicine of Tianjin University of TCM (No. 20110910).

\subsection{Extraction and Isolation}

The dried aerial parts of $R$. officinalis $(2.5 \mathrm{~kg})$ were dealt by using the same method as reported before [2,3]. As results, $\mathrm{CHCl}_{3}$ partition layer $(269 \mathrm{~g}), \mathrm{H}_{2} \mathrm{O}(47 \mathrm{~g})$ and $95 \% \mathrm{EtOH}(45 \mathrm{~g})$ eluted fractions were obtained.

The EtOH fraction (36 g) was subjected to normal phase silica gel CC $\left(\mathrm{CHCl}_{3} \rightarrow \mathrm{CHCl}_{3}-\mathrm{MeOH}\right.$ $\left.(100: 3 \rightarrow 100: 5 \rightarrow 100: 7, v / v) \rightarrow \mathrm{CHCl}_{3}-\mathrm{MeOH}-\mathrm{H}_{2} \mathrm{O}(10: 3: 1 \rightarrow 7: 3: 1, v / v / v) \rightarrow \mathrm{MeOH}\right)$ to yield eleven fractions (Fr. 1-11). Fraction 8 (5480.0 $\mathrm{mg}$ ) was subjected to PHPLC through gradient elution $\left(\mathrm{MeOH}-\mathrm{H}_{2} \mathrm{O}(30: 70 \rightarrow 50: 50 \rightarrow 70: 30 \rightarrow 100: 0, v / v)\right)$ to yield 22 fractions (Fr. 8-1-8-22). Fraction 8-15 (254.6 mg) was separated by PHPLC $\left(\mathrm{CH}_{3} \mathrm{CN}-\mathrm{H}_{2} \mathrm{O}(21: 79, v / v)\right)$ to give fractions 8-15-1 and 8-15-2. Fraction 8-15-1 (59.6 mg) was purified by PHPLC (MeOH- $\left.{ }_{2} \mathrm{O}(44: 56, v / v)\right)$ and $\left(\mathrm{CH}_{3} \mathrm{CN}-\mathrm{H}_{2} \mathrm{O}(19: 81, v / v)\right)$ to yield homoplantaginin (16, $\left.23.0 \mathrm{mg}\right)$. Fraction 8-19 (228.0 mg) was purified by PHPLC $\left(\mathrm{CH}_{3} \mathrm{CN}-\mathrm{H}_{2} \mathrm{O}(25: 75, v / v)\right)$ to give $4^{\prime}, 5$,7-trihydroxy-3'-O- $\beta$-D-glucuronic acid-6" ${ }^{\prime \prime}$-methyl ester $(\mathbf{6}, 36.1 \mathrm{mg})$, tiliadin $(\mathbf{1 0}, 6.3 \mathrm{mg}), 6^{\prime \prime}-O-(E)$-p-coumaroylnepitrin $(\mathbf{1 3}, 21.4 \mathrm{mg})$, and $6^{\prime \prime}-\mathrm{O}-(E)$-feruloylnepitrin $(\mathbf{1 4}, 9.5 \mathrm{mg})$. Fraction $9(10.0 \mathrm{~g})$ was separated by ODS CC $\left(\mathrm{MeOH}-\mathrm{H}_{2} \mathrm{O}\right.$ $(20: 80 \rightarrow 30: 70 \rightarrow 40: 60 \rightarrow 50: 50 \rightarrow 60: 40 \rightarrow 70: 30 \rightarrow$ 100:0, $v / v))$ to yield 14 fractions (Fr. 9-1-9-14). Fraction 9-10 (1510.0 mg) was purified by Sephadex LH-20 CC $\left(\mathrm{CHCl}_{3}-\mathrm{MeOH}(1: 1, v / v)\right)$ to yield eight fractions (Fr. 9-10-1-9-10-8). Fraction 9-10-2 (512.2 mg) was subjected to PHPLC ( $\left.\mathrm{MeOH}-1 \% \mathrm{CH}_{3} \mathrm{COOH}(45: 55, v / v)\right]$ to obtain 14 fractions (Fr. 9-10-2-1-9-10-2-14). Fractions 9-10-2-5 (21.5 mg) and 9-10-2-6 (14.5 mg) were combined and subjected to PHPLC $\left(\mathrm{CH}_{3} \mathrm{CN}-1 \% \mathrm{CH}_{3} \mathrm{COOH}\right.$ $(20: 80, v / v))$ to give homoplantaginin $(\mathbf{1 6}, 10.9 \mathrm{mg})$. Fraction 9-10-4 was separated by PHPLC $\left(\mathrm{MeOH}-1 \% \mathrm{CH}_{3} \mathrm{COOH}(45: 55, v / v)\right)$ to yield 13 fractions (Fr. 9-10-4-1-9-10-4-13). Fraction 9-10-4-12 $(116.0 \mathrm{mg})$ was subjected to silica gel CC $\left(\mathrm{CHCl}_{3}-\mathrm{MeOH}-\mathrm{H}_{2} \mathrm{O}(20: 3: 1, v / v / v) \rightarrow \mathrm{MeOH}\right)$ and PHPLC $\left(\mathrm{CH}_{3} \mathrm{CN}-1 \% \mathrm{CH}_{3} \mathrm{COOH}(24: 76, v / v)\right)$ to give luteolin $3^{\prime}-\mathrm{O}-\beta$-D-glucuronide $(5,14.9 \mathrm{mg})$, luteolin $3^{\prime}$-O-( $3^{\prime \prime}$-O-acetyl)- $\beta$-D-glucuronide $(7,14.5 \mathrm{mg})$, and luteolin $3^{\prime}-O-\left(4^{\prime \prime}-O\right.$-acetyl)- $\beta$-D-glucuronide $(8,9.3 \mathrm{mg})$. Fraction $10(6.3 \mathrm{~g})$ was isolated by PHPLC through gradient elution $\left(\mathrm{MeOH}-\mathrm{H}_{2} \mathrm{O}\right.$ $(25: 75 \rightarrow 40: 60 \rightarrow 60: 40 \rightarrow 80: 20 \rightarrow 100: 0, v / v))$ to yield 35 fractions (Fr. 10-1-10-35). Fraction 10-24 (142.2 mg) was purified by Sephadex LH-20 CC (MeOH) and PHPLC $\left(\mathrm{CH}_{3} \mathrm{CN}-1 \% \mathrm{CH}_{3} \mathrm{COOH}(16: 84\right.$, 
$v / v)$ ) to yield 6-hydroxy luteolin-7-O- $\beta$-D-glucopyranoside (15, $9.0 \mathrm{mg})$. Fraction 10-25 (149.4 mg) was separated by PHPLC $\left(\mathrm{CH}_{3} \mathrm{CN}-1 \% \mathrm{CH}_{3} \mathrm{COOH}(17: 83, v / v)\right)$ to yield six fractions (Fr. 10-25-1-10-25-6). Fraction 10-25-5 (20.8 mg) was further purified by Sephadex LH-20 (MeOH- $\left.\mathrm{H}_{2} \mathrm{O}(50: 50, v / v)\right)$, and luteolin-7-O- $\beta$-D-lutinoside (4, $14.2 \mathrm{mg})$ was obtained. Fraction $10-26(93.7 \mathrm{mg})$ was separated by PHPLC $\left(\mathrm{CH}_{3} \mathrm{CN}-1 \% \mathrm{CH}_{3} \mathrm{COOH}(16: 84, v / v)\right)$ to yield luteolin-7-O- $\beta$-D-glucoside $(3,23.6 \mathrm{mg})$. Fraction 10-27 $(756.1 \mathrm{mg})$ was subjected to Sephadex LH-20 CC (MeOH) to yield nine fractions (Fr. 10-27-1-10-27-9). Fraction 10-27-5 (114.3 mg) was isolated by PHPLC $\left(\mathrm{CH}_{3} \mathrm{CN}-1 \% \mathrm{CH}_{3} \mathrm{COOH}\right.$ $(17: 83, v / v))$ to give both officinoflavonoside B $(2,13.0 \mathrm{mg})$ and apigenin-7-O- $\beta$-D-lutinoside (11, $7.5 \mathrm{mg})$. Furthermore, fraction 10-27-7 $(149.8 \mathrm{mg})$ was purified by PHPLC $\left(\mathrm{CH}_{3} \mathrm{CN}-1 \% \mathrm{CH}_{3} \mathrm{COOH}\right.$ $(20: 80, v / v))$ to yield luteolin $3^{\prime}-\mathrm{O}-\beta$-D-glucuronide $(\mathbf{5}, 28.6 \mathrm{mg})$ and nepitrin $(\mathbf{1 2}, 14.0 \mathrm{mg})$. Fraction 10-28 (473.3 mg) was also subjected to Sephadex LH-20 CC (MeOH) to yield seven fractions (Fr. 10-28-1-10-28-7). Fraction 10-28-6 $(222.0 \mathrm{mg})$ was prepared by PHPLC $\left(\mathrm{CH}_{3} \mathrm{CN}-1 \% \mathrm{CH}_{3} \mathrm{COOH}(20: 80, v / v)\right)$ to give luteolin $3^{\prime}-O-\beta$-D-glucuronide $(5,13.5 \mathrm{mg})$. Furthermore, fraction 10-30 was isolated by Sephadex LH-20 CC (MeOH) and PHPLC $\left(\mathrm{CH}_{3} \mathrm{CN}-1 \% \mathrm{CH}_{3} \mathrm{COOH}(25: 75, v / v)\right)$ to yield officinoflavonoside A (1, $19.0 \mathrm{mg})$. Fraction 10-31 (198.5 mg) was separated by PHPLC $\left(\mathrm{CH}_{3} \mathrm{CN}-1 \% \mathrm{CH}_{3} \mathrm{COOH}(26: 74, v / v)\right)$ to give 4',5,7-trihydroxy-3'-O- $\beta$-D-glucuronic acid-6"'-methyl ester $(6,24.0 \mathrm{mg})$.

The $\mathrm{CHCl}_{3}$ partition $(200 \mathrm{~g})$ of the rosemary extract was subjected to silica gel CC $\left(\mathrm{CHCl}_{3} \rightarrow\right.$ $\mathrm{CHCl}_{3}-\mathrm{MeOH}(100: 1 \rightarrow$ 100:3 $\rightarrow$ 100:5 $\rightarrow 100: 7, v / v) \rightarrow \mathrm{CHCl}_{3}-\mathrm{MeOH}-\mathrm{H}_{2} \mathrm{O}(10: 3: 1 \rightarrow$ 7:3:1, v/v/v) $\rightarrow \mathrm{MeOH}$ ) to yield 23 fractions (Fr. 1-23). Fraction 9 (56.3 g) was further subjected to silica gel CC (Pet. Ether (PE) $\rightarrow$ PE-EtOAc $(20: 1 \rightarrow$ 15:1 $\rightarrow$ 10:1 $\rightarrow$ 5:1 $\rightarrow$ 3:1, $v / v) \rightarrow$ EtOAc) to yield 19 fractions (Fr. 9-1-9-19). Fraction 9-16 (5024.0 mg) was purified by PHPLC ( $\mathrm{MeOH}-\mathrm{H}_{2} \mathrm{O}(90: 10, v / v)$ ), and 13 fractions (Fr. 9-16-1-9-16-13) were given. Fraction 9-16-4 (629.8 mg) was subjected to PHPLC $\left(\mathrm{MeOH}-\mathrm{H}_{2} \mathrm{O}(75: 25, v / v)\right)$ to give acacetin $(9,2.6 \mathrm{mg})$.

Officinoflavonoside $A(\mathbf{1})$ : Yellow powder; $[\alpha]_{\mathrm{D}}^{25}-11.9^{\circ}(c=0.79, \mathrm{MeOH}) ; \mathrm{IR} v_{\max }(\mathrm{KBr}) \mathrm{cm}^{-1}$ : 3209, 2927, 2861, 1736, 1656, 1607, 1505, 1435, 1356, 1301, 1255, 1167, 1081, 1039; UV $\lambda_{\max }(\mathrm{MeOH}) \mathrm{nm}(\log \varepsilon): 335$ (4.20), 265 (4.15). ${ }^{1} \mathrm{H}-\mathrm{NMR}$ (500 MHz, DMSO- $d_{6}$ ) and ${ }^{13} \mathrm{C}-\mathrm{NMR}\left(125 \mathrm{MHz}\right.$, DMSO- $d_{6}$ ) spectroscopic data, see Table 1; HRESI-TOF-MS: Negative-ion mode $m / z 503.0838$ [M - H] $]^{-}$(calcd for $\mathrm{C}_{23} \mathrm{H}_{19} \mathrm{O}_{13}$ 503.0831).

Officinoflavonoside B (2): Yellow powder; $[\alpha]_{\mathrm{D}}^{25}-47.4^{\circ}(c=0.59, \mathrm{MeOH}) ; \mathrm{IR} v_{\max }(\mathrm{KBr}) \mathrm{cm}^{-1}: 3332,2923$, 1658, 1603, 1570, 1514, 1462, 1355, 1276, 1192, 1067, 1014; UV $\lambda_{\max }(\mathrm{MeOH}) \mathrm{nm}(\log \varepsilon): 340$ (4.17), 267 (4.11). ${ }^{1} \mathrm{H}-\mathrm{NMR}\left(500 \mathrm{MHz}, \mathrm{DMSO}-d_{6}\right)$ and ${ }^{13} \mathrm{C}-\mathrm{NMR}\left(125 \mathrm{MHz}\right.$, DMSO- $\left.d_{6}\right)$ spectroscopic data, see Table 2; HRESI-TOF-MS: Negative-ion mode $m / z 6231595[\mathrm{M}-\mathrm{H}]^{-}$(calcd for $\mathrm{C}_{28} \mathrm{H}_{31} \mathrm{O}_{16}$ 623.1618).

$6^{\prime \prime}-O-(E)-p$-Coumaroylnepitrin (13): Yellow powder; The NMR data of $\mathbf{1 3}$ in DMSO- $d_{6}$ are reported for the first time. ${ }^{1} \mathrm{H}-\mathrm{NMR}$ (DMSO- $\left.d_{6}, 500 \mathrm{MHz}\right): \delta 6.70(1 \mathrm{H}, \mathrm{s}, \mathrm{H}-3), 6.96(1 \mathrm{H}, \mathrm{s}, \mathrm{H}-8), 7.45\left(2 \mathrm{H}, \mathrm{m}, \mathrm{H}-2^{\prime}\right.$ and $\left.6^{\prime}\right), 6.89\left(1 \mathrm{H}, \mathrm{d}, J=9.0 \mathrm{~Hz}, \mathrm{H}-5^{\prime}\right), 5.23\left(1 \mathrm{H}, \mathrm{d}, J=7.0 \mathrm{~Hz}, \mathrm{H}-1^{\prime \prime}\right), 3.41\left(1 \mathrm{H}, \mathrm{dd}, J=7.0,9.0 \mathrm{~Hz}, \mathrm{H}-2^{\prime \prime}\right)$, $3.39\left(1 \mathrm{H}, \mathrm{dd}, J=9.0,9.0 \mathrm{~Hz}, \mathrm{H}-3^{\prime \prime}\right), 3.30\left(1 \mathrm{H}, \mathrm{dd}, J=9.0,9.0 \mathrm{~Hz}, \mathrm{H}-4^{\prime \prime}\right), 3.86\left(1 \mathrm{H}, \mathrm{m}, \mathrm{H}-5^{\prime \prime}\right),(4.25(1 \mathrm{H}$, $\mathrm{dd}, J=7.0,12.0 \mathrm{~Hz}), 4.43(1 \mathrm{H}$, br. d, ca. $\left.J=12 \mathrm{~Hz}), \mathrm{H}_{2}-6^{\prime \prime}\right), 7.27\left(2 \mathrm{H}, \mathrm{d}, J=8.5 \mathrm{~Hz}, \mathrm{H}-2^{\prime \prime \prime}, 6^{\prime \prime \prime}\right), 6.60(2 \mathrm{H}$, $\left.\mathrm{d}, J=8.5 \mathrm{~Hz}, \mathrm{H}-3^{\prime \prime \prime}, 5^{\prime \prime \prime}\right), 7.46\left(1 \mathrm{H}, \mathrm{d}, J=16.0 \mathrm{~Hz}, \mathrm{H}-7^{\prime \prime \prime}\right), 6.29\left(1 \mathrm{H}, \mathrm{d}, J=16.0 \mathrm{~Hz}, \mathrm{H}-8^{\prime \prime \prime}\right), 3.77(3 \mathrm{H}, \mathrm{s}$, 6- $\left.\mathrm{OCH}_{3}\right), 13.03$ (1H, br. s, 5-OH). ${ }^{13} \mathrm{C}-\mathrm{NMR}$ (DMSO- $\left.d_{6}, 125 \mathrm{MHz}\right): \delta 164.5$ (C-2), 102.3 (C-3), 182.0 (C-4), 152.5 (C-5), 132.5 (C-6), 156.1 (C-7), 94.0 (C-8), 152.0 (C-9), 105.7 (C-10), 120.8 (C-1'), 113.1 (C-2'), 145.9 $\left(\mathrm{C}-3^{\prime}\right), 150.5\left(\mathrm{C}-4^{\prime}\right), 115.9\left(\mathrm{C}-5^{\prime}\right), 119.0\left(\mathrm{C}-6^{\prime}\right), 99.8\left(\mathrm{C}-1^{\prime \prime}\right), 72.9\left(\mathrm{C}-2^{\prime \prime}\right), 76.3\left(\mathrm{C}-3^{\prime \prime}\right), 69.9\left(\mathrm{C}-4^{\prime \prime}\right), 73.7\left(\mathrm{C}-5^{\prime \prime}\right)$, $63.4\left(\mathrm{C}-6^{\prime \prime}\right), 124.6\left(\mathrm{C}-1^{\prime \prime \prime}\right), 115.5\left(\mathrm{C}-2^{\prime \prime \prime}, 6^{\prime \prime \prime}\right), 129.9\left(\mathrm{C}-3^{\prime \prime \prime}, 5^{\prime \prime \prime}\right), 159.7\left(\mathrm{C}-4^{\prime \prime \prime}\right), 144.9\left(\mathrm{C}-7^{\prime \prime \prime}\right), 113.4\left(\mathrm{C}-8^{\prime \prime \prime}\right)$, $166.4\left(\mathrm{C}-9^{\prime \prime \prime}\right), 60.2\left(6-\mathrm{OCH}_{3}\right)$. Negative-ion mode $\mathrm{m} / z 623.1413[\mathrm{M}-\mathrm{H}]^{-}$(calcd for $\left.\mathrm{C}_{31} \mathrm{H}_{27} \mathrm{O}_{14} 623.1406\right)$.

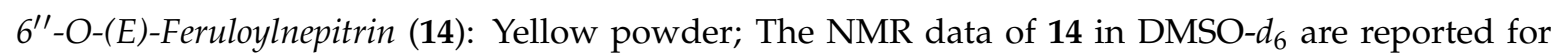
the first time. ${ }^{1} \mathrm{H}-\mathrm{NMR}$ (DMSO- $\left.d_{6}, 500 \mathrm{MHz}\right): \delta 6.63(1 \mathrm{H}, \mathrm{s}, \mathrm{H}-3), 6.95(1 \mathrm{H}, \mathrm{s}, \mathrm{H}-8), 7.39(1 \mathrm{H}, \mathrm{br} . \mathrm{s}$, H-2' $), 6.83\left(1 \mathrm{H}, \mathrm{d}, J=8.0 \mathrm{~Hz}, \mathrm{H}-5^{\prime}\right), 7.39\left(1 \mathrm{H}\right.$, br. d, ca. $\left.J=8 \mathrm{~Hz}, \mathrm{H}-6^{\prime}\right), 5.23\left(1 \mathrm{H}, \mathrm{d}, J=7.0 \mathrm{~Hz}, \mathrm{H}-1^{\prime \prime}\right)$, $3.40\left(1 \mathrm{H}, \mathrm{dd}, J=7.0,9.0 \mathrm{~Hz}, \mathrm{H}-2^{\prime \prime}\right), 3.38\left(1 \mathrm{H}, \mathrm{dd}, J=9.0,9.0 \mathrm{~Hz}, \mathrm{H}-3^{\prime \prime}\right), 3.32(1 \mathrm{H}, \mathrm{dd}, J=9.0,9.0 \mathrm{~Hz}$, $\left.\mathrm{H}-4^{\prime \prime}\right), 3.83\left(1 \mathrm{H}, \mathrm{m}, \mathrm{H}-5^{\prime \prime}\right),\left(4.24(1 \mathrm{H}, \mathrm{dd}, J=6.5,12.0 \mathrm{~Hz}), 4.44(1 \mathrm{H}, \mathrm{br} . \mathrm{d}, \mathrm{ca} . J=12 \mathrm{~Hz}), \mathrm{H}_{2}-6^{\prime \prime}\right), 7.13$ $\left(1 \mathrm{H}\right.$, br. s, H-2'"') $6.60\left(1 \mathrm{H}, \mathrm{d}, J=8.0 \mathrm{~Hz}, \mathrm{H}-5^{\prime \prime \prime}\right), 6.83\left(1 \mathrm{H}\right.$, br. d, ca. $\left.J=8 \mathrm{~Hz}, \mathrm{H}-6^{\prime \prime \prime}\right), 7.45(1 \mathrm{H}, \mathrm{d}$, 
$\left.J=16.0 \mathrm{~Hz}, \mathrm{H}-7^{\prime \prime \prime}\right), 6.37\left(1 \mathrm{H}, \mathrm{d}, J=16.0 \mathrm{~Hz}, \mathrm{H}-8^{\prime \prime \prime}\right), 3.76\left(3 \mathrm{H}, \mathrm{s}, 6-\mathrm{OCH}_{3}\right), 13.07$ (1H, br. s, 5-OH), 3.71 $\left(3 \mathrm{H}, \mathrm{s}, 3^{\prime \prime \prime}-\mathrm{OCH}_{3}\right) .{ }^{13} \mathrm{C}-\mathrm{NMR}$ (DMSO- $\left.d_{6}, 125 \mathrm{MHz}\right): 164.6$ (C-2), 102.1 (C-3), 182.0 (C-4), 152.4 (C-5), 132.4 (C-6), 156.1 (C-7), 94.0 (C-8), 152.0 (C-9), 105.7 (C-10), 120.6 (C-1'), 113.0 (C-2'), 146.0 (C-3'), 150.5 $\left(\mathrm{C}-4^{\prime}\right), 115.8(\mathrm{C}-5), 119.1\left(\mathrm{C}-6^{\prime}\right), 99.8\left(\mathrm{C}-1^{\prime \prime}\right), 73.0\left(\mathrm{C}-2^{\prime \prime}\right), 76.3\left(\mathrm{C}-3^{\prime \prime}\right), 69.7\left(\mathrm{C}-4^{\prime \prime}\right), 73.7\left(\mathrm{C}-5^{\prime \prime}\right), 63.1\left(\mathrm{C}-6^{\prime \prime}\right)$, $125.2\left(\mathrm{C}-1^{\prime \prime \prime}\right), 111.0\left(\mathrm{C}-2^{\prime \prime \prime}\right), 147.7\left(\mathrm{C}-3^{\prime \prime \prime}\right), 149.3\left(\mathrm{C}-4^{\prime \prime \prime}\right), 115.3\left(\mathrm{C}-5^{\prime \prime \prime}\right), 122.7\left(\mathrm{C}-6^{\prime \prime \prime}\right), 145.2\left(\mathrm{C}-7^{\prime \prime \prime}\right), 113.8$ $\left(\mathrm{C}-8^{\prime \prime \prime}\right), 166.4\left({\mathrm{C}-9^{\prime \prime \prime}}^{\prime \prime}\right), 60.2\left(6-\mathrm{OCH}_{3}\right), 55.4\left(3^{\prime \prime \prime}-\mathrm{OCH}_{3}\right)$. Negative-ion mode $\mathrm{m} / \mathrm{z} 653.1514[\mathrm{M}-\mathrm{H}]^{-}$ (calcd for $\mathrm{C}_{32} \mathrm{H}_{29} \mathrm{O}_{15}$ 653.1512).

Acid Hydrolysis of $\mathbf{1}$ and 2. A solution of officinoflavonoside A $(\mathbf{1}, 2.0 \mathrm{mg})$ was hydrolyzed with $10 \% \mathrm{H}_{2} \mathrm{SO}_{4}$ in $50 \% \mathrm{EtOH}(2 \mathrm{~mL})$ at $100{ }^{\circ} \mathrm{C}$ for $3 \mathrm{~h}$. The reaction mixture was neutralized with ion exchange resin Amberlite IRA-400 $\left(\mathrm{OH}^{-}\right.$form) and evaporated to dryness. The sugar was found to be glucuronide by comparison of the $R_{\mathrm{f}}$ value $\left(R_{\mathrm{f}}=0.21\right)$ on TLC plate (silica gel, $\mathrm{CHCl}_{3}-\mathrm{MeOH}-\mathrm{H}_{2} \mathrm{O}$ $(6: 4: 1, v / v / v$, lower layer $))$ with the authentic D-glucuronide.

Meanwhile, a solution of officinoflavonoside B $(2,2.0 \mathrm{mg})$ in $1 \mathrm{M} \mathrm{HCl}(1 \mathrm{~mL})$ was heated under reflux for $3 \mathrm{~h}$, respectively. The reaction mixture was dealt with the similar methods as those used to officinoterpenosides A-D [2]. Identification of L-rhamnose (i) and D-glucose (ii) from 2 presented in the aqueous was carried out by comparison of its retention time and optical rotation with that of authentic samples, $t_{\mathrm{R}}$ : (i) $9.1 \mathrm{~min}$ (negative, L-rhamnose), and (ii) $17.6 \mathrm{~min}$ (positive, D-glucose).

\subsection{Evaluation of Effects on Sodium oleate-induced TG Accumulation in HepG2 Cells}

Materials. A human hepatoma HepG2 cell line was obtained from Cell Resource Center of Institute of Basic Medical Sciences, Chinese Academy of Medical Sciences \& Peking Union Medical College (Beijing, China). Dulbecco's modified Eagle's medium (DMEM), penicillin and streptomycin were purchased from Thermo SCIENTIFIC (Waltham, MA, USA). Fetal Bovine Serum (FBS) was purchased from PAN-Biotech GmbH (Bavaria, Germany). TG assay kits were purchased from Wako Pure Chemical Industries, Ltd. (Osaka, Japan). Sodium oleate and orlistat were obtained from Sigma-Aldrich Corporation (St. Louis, MO, USA).

Cell culture. HepG2 cells were grown in DMEM supplemented with $10 \%$ FBS and 1\% antibiotics (100 unit/mL penicillin and $100 \mathrm{mg} / \mathrm{mL}$ streptomycin). Cells were maintained in an atmosphere of $95 \%$ air and $5 \% \mathrm{CO}_{2}$ at $37^{\circ} \mathrm{C}$ in subconfluent condition.

Sodium oleate-induced TG accumulation. TG accumulation inhibitory effects were screened as previous report [12]. Briefly, Cells were seeded at a density of 100,000 cells/mL on Corning 48-multiwell plates. After $24 \mathrm{~h}$ in culture, medium was exchanged for phenol red free-DMEM with or without Sodium oleate $(200 \mu \mathrm{mol} / \mathrm{L})$ in the presence or absence of the obtained isolates $(30 \mu \mathrm{mol} / \mathrm{L})$ from R. officinalis for another $48 \mathrm{~h}$. Meanwhile, an anti-obesity drug, orlistat $(5 \mu \mathrm{mol} / \mathrm{L})$, was used as a positive control. Cells were then rinsed with phosphate buffered saline twice and $200 \mu \mathrm{L}$ deionized water was added per well to get cell lysate by ultrasonication. Intracellular TG contents in the lysates were finally evaluated using a GPO-POD method as the kit protocol provided. Briefly, the method is based on the enzymatic hydrolysis of triglyceride to glycerol and free fatty acids by lipoprotein lipase. The glycerol is phosphorylated by adenosine triphosphate in the presence of glycerolkinase to form glycerol-3-phosphate and adenosine diphosphate. glycerol-3-phosphate is oxidized by glycerophosphate oxidase (GPO) to form dihydroxyacetone phosphate and hydrogen peroxide. Purple quinoneimine complex is produced by the peroxidase (POD) catalyzed coupling of and 4AAP and ESPAS with hydrogen peroxide. The final absorbance was monitored at $492 \mathrm{~nm}$ using a microplate reader (Molecular Devices, Sunnyvale, CA, USA). Concentration setting of test sample and orlistat were established by pre-test results. Under the concentration, there were no treatment-related changes in cell viability (Data not shown).

Oil red $O$ staining After a 48 h-treatment in 24-multiwell plates, cells were washed with phosphate-buffered saline (PBS) and fixed in 10\% paraformaldehyde for $30 \mathrm{~min}$ at room temperature, followed by washing twice with deionized water and incubated in Oil Red O working solution (water at a 3:2 ratio of stock solution, which prepared by $0.5 \%$ Oil Red O dye in isopropanol) for $1 \mathrm{~h}$. The unbound 
dye was removed by washing with $75 \%$ ethyl alcohol for once and images were immediately captured under an inverted phase contrast microscope (Leica, Wetzlar, Germany). For quantitative analysis, stained cells were then dissolved in isopropanol and absorbance was measured at $492 \mathrm{~nm}$.

\subsection{Statistical Analysis}

Statistical analysis was performed using one-way ANOVA with the Tukey's test for multiple comparisons. All data were expressed as mean \pm S.E.M. and values of $p<0.05$ were considered significant.

\section{Conclusions}

Taken together, 16 flavonoids (1-16) including two new ones, officinoflavonosides A (1) and B (2), were obtained from the aerial parts of $R$. officinalis. Among the known ones, 6, 10, and 13 were isolated from the rosmarinus genus for the first time, and the NMR data of 13 and 14 in DMSO- $d_{6}$ were reported for the first time. Their structures were elucidated by chemical and spectroscopic methods and their effects on TG accumulation were analyzed in HepG2 cells. The results showed that six kinds of flavonoids (compounds 3, 6, 7, 8, 9 and 11) together with the two novel ones (compounds 1 and 2) and seven kinds of other known isolates (compounds 17, 18, 19, 20, 23, 26 and 31) possessed significant inhibitory activities on TG accumulation in vitro. Among them, the activities of compounds $\mathbf{1}$ and $\mathbf{2 0}$ were comparable to that of orlistat, which suggested that these compounds contained in the R. officinalis might be involved in the lipid metabolism.

Acknowledgments: Part of this research was supported by Programs for New Century Excellent Talents in University (NCET-12-1069), and National Natural Science Foundation of China (81673688).

Author Contributions: Yi Zhang and Tao Wang designed the research and wrote the manuscript; Jian Li, Tiwalade Adegoke Adelakun, and Sijian Wang performed the experimental work; Shengcai Yang and Xiaoxia Li retrieved literature; Jingya Ruan perfected language. All authors discussed, edited and approved the final version.

Conflicts of Interest: The authors declare no conflict of interest.

\section{References}

1. Moore, J.; Yousef, M.; Tsiani, E. Anticancer Effects of Rosemary (Rosmarinus officinalis L.) Extract and Rosemary Extract Polyphenols. Nutrients 2016, 8, 731. [CrossRef] [PubMed]

2. Zhang, Y.; Adelakun, T.A.; Qu, L.; Li, X.; Li, J.; Han, L.; Wang, T. New terpenoid glycosides obtained from Rosmarinus officinalis L. aerial parts. Fitoterapia 2014, 99C, 78-85. [CrossRef] [PubMed]

3. Li, Z.; Chen, Z.; Li, X.; Xu, Q.; Yang, S. Chemical constituents in roots and stems of Physalis alkekengi var. franchetii. Zhongcaoyao 2012, 43, 1910-1912.

4. Ren, Y.; Yang, J. Study on chemical constituents of Saussurea tridactyla Sch-Bip II. Zhongguo Yaoxue Zazhi 2001, 36, 590-593.

5. Okamura, N.; Haraguchi, H.; Hashimoto, K.; Yagi, A. Flavonoids in Rosmarinus officinalis leaves. Phytochemistry 1994, 37, 1463-1466. [CrossRef]

6. Sathiamoorthy, B.; Gupta, P.; Kumar, M.; Chaturvedi, A.K.; Shukla, P.K.; Mauryam, R. New antifungal flavonoid glycoside from Vitex negundo. Bioorg. Med. Chem. Lett. 2007, 17, 239-242. [CrossRef] [PubMed]

7. Na, Z.; Feng, Y.; Xu, Y. Chemical constituents from aerial parts of Eupatorium odoratum. Zhongcaoyao 2012, 43, 1896-1900.

8. Chen, S.; Wang, L.; Gao, G.; Liao, M.; Xiao, P. Studies on flavonoids from Aquilegia oxysepala. Zhongguo Zhongyao Zazhi 1999, 24, 158-160. [PubMed]

9. Zheng, D.; Zhang, X.-Q.; Wang, Y.; Ye, W.-C. Chemical constituents of the aerial parts of Blumea riparia. Zhongguo Tianran Yaowu 2007, 5, 421-424.

10. Pan, C.; Zhang, G.; Mi, W.; Chenm, L.; Wang, Q.; He, J. Flavoniod glycosides from whole plant of Leontopodium leontopodioides (Wild.) Beauv. Shenyang Yaoke Daxue Xuebao 2009, 26, 886-888.

11. Wu, F.-H.; Liang, J.-Y.; Chen, R.; Wang, Q.-Z.; Li, W.-G. Chemical constituents and hepatoprotective activity of Plantago depressa. Zhongguo Tianran Yaowu 2006, 4, 435-439. 
12. Gao, J.; Li, J.; An, Y.; Liu, X.; Qian, Q.; Wu, Y.; Zhang, Y.; Wang, T. Increasing effect of Tangzhiqing formula on IRS-1-dependent PI3K/AKT signaling in muscle. BMC Complement. Altern. Med. 2014, 14, 198. [CrossRef] [PubMed]

Sample Availability: Sample Availability: Samples of all the compounds are available from the authors.

(C) 2017 by the authors; licensee MDPI, Basel, Switzerland. This article is an open access article distributed under the terms and conditions of the Creative Commons Attribution (CC-BY) license (http://creativecommons.org/licenses/by/4.0/). 